\title{
Sociological Evaluation and Analysis of the Social Issue of Divorce and Addiction among Families of Iranian Martyrs Case Study: Province of Guillan
}

\author{
Seyed Rahmat Mozafari
}

\author{
PhD, Sociology, Baku Public University; Email:dr.mozafari_61@yahoo.com
}

\section{Doi:10.5901/mjss.2016.v7n4s2p169}

\begin{abstract}
Family is the first social institute and sociologists consider its advent concurrent with arising of individual ownership. From ancient time, the institute of family was the first and most important social platform for socialization of individuals and learning social teachings, values and norms. This structure is a remnant of centuries ago and has continuously had various functions which has led to its strengthening and sustenance and has given it a "holy" appearance and function. In this paper, we will sociologically evaluate and analyze the social issue of divorce and addiction. For the purpose of data collection, in this study a researcher prepared questionnaire, study of social work files and interview were used. Additionally, in this research descriptive and inferential statistical methods were used. The data was analyzed with the help of SPSS statistical software.
\end{abstract}

Keywords: Contemporary Society, Divorce, Addiction, Martyrs, Iran, Guillan Province

\section{Introduction}

Social issues look over the condition and situation that in the opinion of most individuals of society disrupts quality of life of individuals and social groups, endangers the most important general values and despite much effort by most people, their legitimate objectives are not achievable. Some of these individuals and social groups come to the belief that for changing the conditions and revising the current situation, they need to take social action (Sarvestani, Sadigh, 2004). In fact, the root of social issues lies in the heart of social institutes and arises due to their inappropriate functioning and enforces difficult and painful conditions on most people and gains objective and cognitive aspects to itself. Social issues bear on main society and in time can lead to injury for individuals, provide platforms for deviation and in some cases where they are accompanied with legal repercussions, they can transform into social pathology. Unlike social issues, individual issues are related to the person's situation and his or her immediate relationship with others. Social issues and pathologies are so interweaved that they recreate each other such that in understanding important social issues, implicit contexts of creation of issues is revealed and on this basis and in addressing social issues, the approach of consideration of the mass and social structure becomes manifest to the individual. In addition, addressing social issues and problems requires formation of thoughts and theories, discussions and software programming so on this basis, by way of thinking, creativity, real participation of people in the community, transformation in the present situation can happen. On this basis, social issues overlook difficult conditions and social pathologies, actions of individuals and social groups.

\section{Statement of the Problem}

Family is a primary and critical social institute that provides for health of the individual and also sustenance of society and guarantees it. No society can reach its goals and objectives without having a system of thinking and implementation of programs for care of and health of the family. In their path of growth and reaching excellence, families at times face various challenges and difficulties. The severity and influence of these hardships in some cases lead to formation of social problems and occurrence of social pathology. Occurrence of unforeseen and un-predetermined events such as floods, earthquakes, war, fire and etc can disrupt the foundation and pillars of the families or make them face numerous problems and challenges. The country of Iran during the 8 years of forced war underwent hundreds of milliards of dollars financial damages. More than 213255 individuals became martyrs and near 472000 veterans and more than 50 thousands survived or became prisoners of war. Unfortunately, in some cases, the praised families of martyrs, veterans, free, prisoners and devotees due to losing the family guardian or lack of effective and appropriate role creation for a family caretaker encountered various social problems and issues. Among the most important problems encountered by 
families of martyrs in recent years has been increased divorce among the offspring. In the opinion of Ahmadi (2008), children who grow up in single parent environments, because of lack of familiarity with both parents as teaching models, at times are less successful in performing the role of a spouse. This group of offspring precisely because of lacking appropriate styles of interaction with their spouses and lack of necessary skills become dysfunctional. Enzioni believes that lack of a guardian in the family, in addition to inflicting economic shock, will also have consequences with regards to methods and styles of upbringing of the children. He believes that this influence is witnessed in male offspring. Lack of familiarity in this group of boys with styles of running a family, doubts and failure in problem solving skills, expression of anger and aggression in their shared life, interest in separation and divorce are consequences of lack of a family guardian and such environments (Enzioni, 2004). On the other hand, the average rate of divorce among offspring that were not blessed with having a father has been reported higher that the mean rate of divorce in society (Haji Dehabadi, 2000).

Nature and characteristics of social problems and difficulties of families of martyrs:

Social issues have persistently been topic of discussion and dispute. Some consider the extent of destructive effect of a phenomenon a reason for it being considered a problem. Some consider inclusiveness and breadth of a topic involving all levels of society and some consider unanimity of the people regarding an issue a sign of it being a social problem. Perceptions forcefully in social engineering lead to various methods of solving social problems; methods that at times lead to an impasse and make the problem complex and difficult. Social issues in the contemporary world are newly arising phenomena. Naturally, evolutions in society have led to increased attention to the discussion of social issues. The first sources of social issues have been in the West and the nineteenth century where the industrial revolution and various other social uprisings have created various unrests in western societies. Under such conditions, intellectual and belief systems and molds had weakened and ultimately, society without having specific and determined criteria moved towards widespread disorder. In the opinion of some individuals, these conditions led to the science of sociology. The reason is that there was need for a science to present a new definition and analysis for the existing situation and ultimately bring order to the disrupted society. Even though it took close to two centuries for those irregularities to gradually become organized and take form. It was under such critical situation that social issues were set forth to discussion. Change in foundational structures of society from the past and up to now has made social issues an inseparable part of the nature of societies. In other words, we cannot find a society that has undergone modern evolution, yet, it has not faced social issues. In this regards, difference does not exist among communities. Therefore, now a day social issues are among the necessities of our lives. In defining social issues, two approaches are recognizable. The classic approach considers social issues an objective and external problem, abnormalities and events that disrupt social order and balance and involves most people in that problem. In modern approaches, social issues are cognitive matters.

In other words, what is considered disorder by most people in society is considered a social issue. In the nineteenth century in Europe and after World War II in Iran, social issues were evident and tangible. Issues such as poverty, organized crime and social problems are examples. Yet, now a day many of the matters that may not even be very expansive are considered social issues. One of the reasons for this is increased sensitivity of society which has led anything even if mundane to be considered important. Therefore, in the modern approach, social problem refers to how people think and what they consider to be a problem.

\section{Historical Background}

\subsection{In the world}

Lamnery and Husung (2007) in a research evaluated the level of crime among children without father in Michigan, America. Their findings showed that in single parent families, adolescents and youth have increased tendency towards delinquency. Laussen (2008) in a research evaluated the situation of addiction among youth in outskirt dwellers of Florida. In this research which was performed as a field study, results show that the higher the level of parental control on youth, the less will gravitation to addiction be. Sumner (2003) in a research evaluated social pathologies among delinquent children of Oklahoma. Comparative research of this investigator shows that delinquent children have had less internal and external systems of control in their lives.

\subsection{Research Background in Iran}

Mohammadian (2005) in a research evaluated the level of prevalence of psychological disorders among children of martyrs and compared them with non-martyr families. Results of this research show that martyrs' children acquired higher scores in some axes such as dependent personality, antisocial personality disorder and hysteric personality disorder 
compared to regular counterparts and higher levels of disorder were reported.

Ahmadpanah (2006) in a research evaluated the level of gravitation to addiction among children of Martyrs. Result of his research showed that tendency towards addiction is less in children of martyrs compared to regular counterparts.

Jahanara and Edalatkhah (2005) in a research evaluated coping skills among children of martyrs. Findings of this field study with participation of 315 children of martyrs (girl and boy 18-25 years) showed that most participants in the research used appropriate cognitive coping skills in facing life stresses (Nafisi \& Yazdi, 2004). In a research, factors influential on divorce were investigated. In the opinion of the researchers, couples with history of 1-5 years of marriage experienced more problems with problems such as family intrusion, economic hardships, housing and cultural difference compared to couples with 11-15 years of marital history. Additionally, results of this research showed that socio-economic indices, education before marriage, income and occupation also have predicting power over stability of marital situation. Rahmatollahi (2006: 227) in a research regarding influential factors on divorce reached the conclusion that financial problems are among the most important elements in marital disagreement in many of the cases. In his opinion, tension inducing changes occur more in marriages were individuals are young in age, lack education, and are unemployed or low in income.

\section{Research Findings}

Table 1: Distribution of number of respondents based on gender and most common social problems in families of martyrs

\begin{tabular}{|c|c|c|c|c|c|c|}
\hline \multirow{2}{*}{ Gender } & \multicolumn{2}{|c|}{ Male } & \multicolumn{2}{c|}{ Female } & \multicolumn{2}{c|}{ Total } \\
\cline { 2 - 7 } Social probtem & Number & Percent & Number & Percent & Number & Percent \\
\hline Addiction & 72 & 18 & 51 & $12 / 75$ & 123 & $30 / 7$ \\
\hline Divorce & 46 & $11 / 5$ & 48 & 12 & 94 & $23 / 5$ \\
\hline Suicide & 18 & $4 / 5$ & 28 & 7 & 46 & $11 / 5$ \\
\hline Homicide & 4 & 1 & 2 & $0 / 5$ & 6 & $1 / 5$ \\
\hline Theft & 4 & 1 & 2 & $0 / 5$ & 6 & $1 / 5$ \\
\hline Prostitution & 3 & $0 / 75$ & 4 & 1 & 7 & $1 / 75$ \\
\hline Unemployment & 65 & $16 / 25$ & 42 & $10 / 5$ & 107 & $26 / 75$ \\
\hline Other & 8 & 2 & 3 & $0 / 75$ & 11 & $2 / 75$ \\
\hline Total & 220 & 55 & 1 & 45 & 400 & 100 \\
\hline
\end{tabular}

Based on the data in the above table, it can be stated that the social issue of addiction is the most concerning in families of martyrs and it is the most important and prevalent social problem among these families (30/75 percent).

Unemployment is the second most prevalent social issue among families of martyrs (26/75 percent) and following that is the problem of divorce (23/5 percent).

Table 2. Distribution of number of respondents based on number of family members and gender

\begin{tabular}{|c|c|c|c|c|c|c|}
\hline \multirow{2}{*}{$\begin{array}{c}\text { Gender } \\
\text { Number }\end{array}$} & \multicolumn{2}{|c|}{ Male } & \multicolumn{2}{c|}{ Female } & \multicolumn{2}{c|}{ Total } \\
\cline { 2 - 7 } & Number & Percent & Number & Percent & Number & Percent \\
\hline 2 & 21 & $5 / 25$ & 18 & $4 / 5$ & 39 & $9 / 75$ \\
\hline 3 & 33 & $8 / 25$ & 34 & $8 / 5$ & 67 & $16 / 75$ \\
\hline 4 & 68 & 17 & 53 & $13 / 25$ & 121 & $30 / 25$ \\
\hline 5 & 47 & $11 / 75$ & 32 & 8 & 79 & $19 / 75$ \\
\hline 6 and higher & 51 & $12 / 75$ & 43 & $10 / 75$ & 94 & $23 / 5$ \\
\hline Total & 220 & 55 & 180 & 45 & 400 & 100 \\
\hline
\end{tabular}

Data from the above table show that the highest number of participants in this research was related to families with 4 members and the lowest number was related to families with 2 members ( $9 / 75$ percent). Additionally, based on the data of the above table, it can be stated that 23/5 percent of participants in this research have families with 6 members and higher. 
Table 3. Distribution of number of respondents based on gender and income level

\begin{tabular}{|c|c|c|c|c|c|c|}
\hline \multirow{2}{*}{$\begin{array}{c}\text { Gender } \\
\text { Incomelevel }\end{array}$} & \multicolumn{2}{|c|}{ Male } & \multicolumn{2}{c|}{ Female } & \multicolumn{2}{c|}{ Total } \\
\cline { 2 - 7 } & Number & Percent & Number & Percent & Number & Percent \\
\hline Very good & 41 & $10 / 25$ & 17 & $4 / 25$ & 58 & $14 / 5$ \\
\hline Good & 38 & $9 / 5$ & 38 & $9 / 5$ & 76 & 19 \\
\hline Average & 85 & $21 / 25$ & 81 & $20 / 25$ & 166 & $41 / 5$ \\
\hline Low & 56 & 14 & 44 & 11 & 100 & 25 \\
\hline Total & 220 & 55 & 180 & 45 & 400 & 100 \\
\hline
\end{tabular}

Based on the data in the above table, it can be stated that $41 / 5$ percent of participants in this research evaluated the level of their income as average. Twenty five percent described their income level low and 19 percent as good.

Table 4. Distribution of number of respondents based on social strata and gender

\begin{tabular}{|c|c|c|c|c|c|c|}
\hline \multirow{2}{*}{$\begin{array}{c}\text { Gender } \\
\text { Social strata }\end{array}$} & \multicolumn{2}{|c|}{ Male } & \multicolumn{2}{c|}{ Female } & \multicolumn{2}{c|}{ Total } \\
\cline { 2 - 7 } & Number & Percent & Number & Percent & Number & Percent \\
\hline High & 30 & $7 / 5$ & 42 & $10 / 5$ & 72 & 18 \\
\hline Average & 116 & 29 & 98 & $24 / 5$ & 214 & $53 / 5$ \\
\hline Low & 74 & $18 / 5$ & 40 & 10 & 114 & $28 / 5$ \\
\hline Total & 220 & 55 & 180 & 45 & 400 & 100 \\
\hline
\end{tabular}

Based on the data in the above table, it can be stated that more than half of the respondents reported their social strata as average.

Table 5. Distribution of opinion of respondents based on gender and the social issues of Iran exercise

\begin{tabular}{|c|c|c|c|c|c|c|}
\hline Gender & \multicolumn{2}{|c|}{ Male } & \multicolumn{2}{c|}{ Female } & \multicolumn{2}{c|}{ Total } \\
\cline { 2 - 7 } Social probtem & Number & Percent & Number & Percent & Number & Percent \\
\hline Drugs of abuse & 44 & 11 & 39 & $9 / 75$ & 83 & $20 / 75$ \\
\hline Divorce & 39 & $9 / 75$ & 32 & 8 & 71 & $17 / 75$ \\
\hline Homicide & 11 & $2 / 75$ & 6 & $1 / 5$ & 17 & $4 / 25$ \\
\hline Prostitution & 48 & 12 & 30 & $7 / 5$ & 78 & $19 / 5$ \\
\hline Suicide & 20 & 5 & 36 & 9 & 56 & 14 \\
\hline Unemployment & 24 & 6 & 17 & $4 / 25$ & 41 & $10 / 25$ \\
\hline Theft & 27 & $6 / 75$ & 18 & $4 / 5$ & 45 & $11 / 25$ \\
\hline Other & 7 & $1 / 75$ & 2 & $0 / 5$ & 9 & $2 / 25$ \\
\hline Total & 220 & 55 & 180 & 45 & 400 & 100 \\
\hline
\end{tabular}

In the opinion of the participants in this research, the topic of addiction and substances of abuse is the most important and challenging social issue currently in the country (20/75 percent). Next, is the topic of prostitution and lewdness and its expansion is a matter of concern for families of martyrs (19/5 percent). Also, increased divorce in the country (17/75 percent) is the third social issue mentioned.

Table 6. Distribution of number of respondents regarding extent of actions taken by the government for resolution of problems of families of martyrs

\begin{tabular}{|c|c|c|c|c|c|c|}
\hline \multirow{2}{*}{ Govender } & \multicolumn{2}{|c|}{ Male } & \multicolumn{2}{c|}{ Female } & \multicolumn{2}{c|}{ Total } \\
\cline { 2 - 7 } Govmentataction & Number & Percent & Number & Percent & Number & Percent \\
\hline Very much & 36 & 9 & 42 & $10 / 5$ & 78 & $19 / 5$ \\
\hline Much & 45 & $11 / 25$ & 52 & 13 & 97 & $24 / 25$ \\
\hline Sufficient & 69 & $17 / 25$ & 55 & $13 / 75$ & 124 & 31 \\
\hline Little & 46 & $11 / 5$ & 22 & $5 / 5$ & 68 & 17 \\
\hline Very little & 24 & 6 & 9 & $2 / 25$ & 33 & $8 / 25$ \\
\hline Total & 220 & 55 & 180 & 45 & 400 & 100 \\
\hline
\end{tabular}


The data in the above table shows that 31 percent of the respondents believed that the actions taken by the government to solve problems of families of martyrs has been sufficient. 24/25 percent considered the efforts by the government to resolve problems of martyrs' families very little and 17 percent also considered it little.

Table 7. Correlation matrix for income level and social problems of families of martyrs

\begin{tabular}{|c|c|c|c|}
\hline $\begin{array}{c}\text { Income level } \\
\text { Indices of social probtems }\end{array}$ & High income & Average income & Low income \\
\hline Substances of abuse & $0 / 053$ & $0 / 208^{*}$ & $* * 0 / 130$ \\
\hline Divorce & $0 / 057$ & $0 / 138^{*}$ & $* * 0 / 208$ \\
\hline Homicide & $0 / 340^{*}$ & $0 / 210^{*}$ & $* 0 / 166$ \\
\hline Prostitution & $0 / 050$ & $0 / 152^{*}$ & $* 0 / 212$ \\
\hline Suicide & $-0 / 042$ & $0 / 118^{*}$ & $* 0 / 128$ \\
\hline Unemployment & $0 / 128^{*}$ & $0 / 014$ & $* 0 / 191$ \\
\hline Theft & $0 / 034$ & $0 / 166^{*}$ & $* 0 / 143$ \\
\hline Rape & $0 / 058$ & $0 / 118^{*}$ & $* 0 / 102$ \\
\hline AIDS & $-0 / 061$ & $0 / 054$ & $* 0 / 126$ \\
\hline Running away from home & $0 / 127^{*}$ & $0 / 177^{* *}$ & $* * 0 / 144$ \\
\hline
\end{tabular}

The data in the above table show that meaningful correlation exists between indices of various social issues and income level in families of veterans and martyrs.

Table 8. Comparison of statistical indices of mean, variance and standard deviation of scores of respondents regarding social issues of families of martyrs and veterans

\begin{tabular}{|c|c|c|c|c|c|}
\hline Row & $\begin{array}{c}\text { Statistical index } \\
\text { Variables }\end{array}$ & $\begin{array}{c}\text { Number } \\
\mathrm{N}\end{array}$ & $\begin{array}{c}\text { Mean } \\
\bar{X}\end{array}$ & $\begin{array}{c}\text { Variance } \\
\mathrm{S}^{2}\end{array}$ & $\begin{array}{c}\text { Standard deviation } \\
\mathrm{S}\end{array}$ \\
\hline 1 & Substances of abuse & 400 & $73 / 82$ & $66 / 75$ & $8 / 17$ \\
\hline 2 & Divorce & 400 & $61 / 42$ & $83 / 17$ & $9 / 12$ \\
\hline 3 & Homicide & 400 & $48 / 18$ & $68 / 10$ & $8 / 25$ \\
\hline 4 & Prostitution & 400 & $38 / 52$ & $46 / 51$ & $6 / 82$ \\
\hline 5 & Suicide & 400 & $46 / 47$ & $50 / 98$ & $7 / 14$ \\
\hline 6 & Unemployment & 400 & $57 / 68$ & $67 / 10$ & $8 / 19$ \\
\hline 7 & Theft & 400 & $34 / 71$ & $57 / 30$ & $7 / 57$ \\
\hline 8 & Rape & 400 & $36 / 26$ & $98 / 40$ & $9 / 92$ \\
\hline 9 & AlDS & 400 & $70 / 68$ & $69 / 72$ & $8 / 35$ \\
\hline 10 & Running away from home & 400 & $44 / 65$ & $98 / 40$ & $9 / 92$ \\
\hline
\end{tabular}

Table 9. Coefficients from concurrent regression analysis of social issues based on predicting variables

\begin{tabular}{|c|c|c|c|c|c|c|}
\hline $\begin{array}{c}\text { Statistical indices } \\
\text { Variables }\end{array}$ & $\mathrm{B}$ & $\begin{array}{c}\text { Standard error } \\
\text { SE }\end{array}$ & Beta & $\mathrm{t}$ & $\mathrm{Sig}$ & $\begin{array}{c}\text { Correlation } \\
\text { coefficient }\end{array}$ \\
\hline Constant value & $3 / 948 \mathrm{E}$ & $1 / 730$ & $0 / 055$ & $2 / 282$ & $0 / 023$ & - \\
\hline Substances of abuse & $2 / 532 \mathrm{E}$ & $0 / 023$ & $0 / 124$ & $2 / 130$ & $0 / 053$ & $0 / 10$ \\
\hline Divorce & $2 / 812 \mathrm{E}$ & $0 / 027$ & $0 / 168$ & $0 / 898$ & $0 / 535$ & $0 / 02$ \\
\hline Homicide & $3 / 122 \mathrm{E}$ & $0 / 035$ & $0 / 036$ & $2 / 462$ & $0 / 017$ & $0 / 12$ \\
\hline Prostitution & $5 / 213 \mathrm{E}$ & $0 / 034$ & $0 / 028$ & $2 / 524$ & $0 / 045$ & $0 / 12$ \\
\hline Suicide & $3 / 496 \mathrm{E}$ & $0 / 042$ & $0 / 030$ & $0 / 914$ & $0 / 419$ & $0 / 021$ \\
\hline Unemployment & $3 / 182 \mathrm{E}$ & $0 / 040$ & $0 / 172$ & $0 / 852$ & $0 / 332$ & $0 / 03$ \\
\hline Theft & $2 / 628 \mathrm{E}$ & $0 / 038$ & $0 / 210$ & $0 / 753$ & $0 / 385$ & $0 / 04$ \\
\hline Rape & $3 / 275 \mathrm{E}$ & $0 / 022$ & $0 / 041$ & $2 / 417$ & $0 / 002$ & $0 / 13$ \\
\hline AlDS & $1 / 17 \mathrm{E}$ & $0 / 026$ & $0 / 027$ & $0 / 666$ & $0 / 245$ & $0 / 03$ \\
\hline Running away from home & $3 / 126 \mathrm{E}$ & $0 / 042$ & $0 / 024$ & $0 / 382$ & $0 / 000$ & $0 / 10$ \\
\hline
\end{tabular}

The data in the above table show that families of martyrs and veterans show more concern regarding some social problems such as suicide, divorce, addiction, unemployment and theft in society. 
Table 10. Situation of divorce in families of martyrs in the Guillan province

\begin{tabular}{|c|c|c|c|c|c|c|c|c|c|c|c|c|c|c|c|c|}
\hline \multicolumn{2}{|c|}{$\begin{array}{l}\text { Divorce } \\
\text { in family }\end{array}$} & \multicolumn{3}{|c|}{ Family member } & \multicolumn{7}{|c|}{ Reason for separation } & \multicolumn{2}{|c|}{$\begin{array}{l}\text { Awareness } \\
\text { of reason for } \\
\text { separation }\end{array}$} & \multicolumn{3}{|c|}{$\begin{array}{l}\text { Was lack of father } \\
\text { reason for divorce? }\end{array}$} \\
\hline Yes & No & $\begin{array}{l}\text { Mother } \\
\text { or } \\
\text { Father }\end{array}$ & Daughter & Son & IIIness & Unemployment & $\begin{array}{c}\text { Psychological } \\
\text { problems }\end{array}$ & $\begin{array}{c}\text { Lack of } \\
\text { compatibility }\end{array}$ & addiction & $\begin{array}{c}\text { Betray } \\
\text { al }\end{array}$ & other & Yes & No & Yes & No & $\begin{array}{c}\text { No } \\
\text { response }\end{array}$ \\
\hline 56 & 344 & 13 & 21 & 22 & 5 & 15 & 9 & 10 & 12 & 3 & 2 & 35 & 9 & 9 & 41 & 6 \\
\hline 14 & 86 & $32 / 2$ & $37 / 5$ & $39 / 3$ & $8 / 9$ & $26 / 8$ & 16 & $17 / 9$ & $21 / 4$ & $5 / 4$ & $3 / 6$ & $26 / 5$ & $37 / 5$ & 16 & $73 / 3$ & $10 / 7$ \\
\hline
\end{tabular}

The data in the above table shows that from among all participants in the research 14 percent (56 individuals) have experienced divorce in their families. From among them, 39/3 percent of the divorce was related to martyr sons, $37 / 5$ percent to martyr daughters. Regarding the reason for divorce and separation in families of martyrs, the highest number was related to unemployment (26/8 percent), addiction (21/4 percent) and lack of compatibility (17/9 percent). $73 / 3$ percent of respondents believed that lack of father in the family of martyrs has not led to divorce and only 16 percent stated that lack of father has led to divorce in the family.

Table 11. Situation of quitting drug abuse in families of martyrs in the province of Guillan

\begin{tabular}{|c|c|c|c|c|c|c|c|c|c|c|c|c|c|c|c|c|c|c|}
\hline \multicolumn{2}{|c|}{ Quit attempt } & \multicolumn{4}{|c|}{ Number of times quit } & \multicolumn{4}{|c|}{ Method of quit } & \multicolumn{6}{|c|}{ Reason for addiction } & \multicolumn{3}{|c|}{$\begin{array}{l}\text { Was lack of father } \\
\text { reason for addiction? }\end{array}$} \\
\hline Yes & No & 1 & $2-5$ & $\begin{array}{c}6 \text { or } \\
\text { more }\end{array}$ & Hospitalization & outpatient & $\begin{array}{l}\text { Needle } \\
\text { therapy }\end{array}$ & $\begin{array}{l}\text { Camp } \\
\text { and } \\
\text { NA }\end{array}$ & $\begin{array}{l}\text { Combined } \\
\text { treatment }\end{array}$ & $\begin{array}{l}\text { Pain } \\
\text { and } \\
\text { illness }\end{array}$ & $\begin{array}{r}\text { Inappropriate } \\
\text { environment }\end{array}$ & $\begin{array}{l}\text { Emotional } \\
\text { emptyness }\end{array}$ & $\begin{array}{c}\text { To } \\
\text { improve } \\
\text { sexual } \\
\text { desire }\end{array}$ & $\begin{array}{l}\text { Unempl } \\
\text { oyment }\end{array}$ & Other & Yes & No & $\begin{array}{c}\text { No } \\
\text { response }\end{array}$ \\
\hline 60 & 23 & 18 & 45 & 20 & 14 & 14 & 1 & 32 & 7 & 14 & 18 & 21 & 8 & 14 & 8 & 12 & 44 & 27 \\
\hline $72 / 3$ & $27 / 7$ & $32 / 17$ & $54 / 3$ & 24 & $16 / 9$ & $16 / 9$ & $1 / 2$ & $38 / 5$ & $8 / 4$ & $16 / 9$ & $21 / 7$ & $52 / 3$ & $9 / 6$ & $16 / 9$ & $9 / 6$ & $14 / 4$ & 53 & $32 / 5$ \\
\hline
\end{tabular}

The data in the above table shows that from among the respondents of this research, 83 individuals (20/75 percent) had experienced addiction in their family and 79/25 percent had not had addiction problem. From among the families with addiction experience, the highest number of cases was related to sons of martyrs (39/7 percent) and the least number to mothers of martyrs ( $4 / 8$ percent) and daughters of martyrs ( $7 / 2$ percent). Regarding the substance of abuse, 49/4 percent noted using opium for more than one year. Additionally, three fourth of the addicts had attempted to quit and more than half had quit attempts of 2-5 tries. Also, the most common method of quit was camps and participation in NA sessions (Narcotic Anonymous) (38/5 percent) and method of hospitalization (34/9 percent). Regarding cause of addiction, 25/3 percent mentioned emotional emptiness in the family and $21 / 7$ percent inappropriate environmental conditions and 16/9 percent unemployment.

\section{Conclusion}

Principally, social issues lead to abnormalities, anomy and disturbance in social norms. In the opinion of Guidenz (2009), in today's societies traditional criteria and norms without being replaced with new norms are weakened. Abnormality exists when clear criteria for guiding individuals in the domain of the meaning of social life do not exist. Under such conditions, in the opinion of Durkheim, people have a feeling of losing their sense of direction and become worried and this is among social factors that lead to suicidal tendencies. Apparently, in the current society, some economic concerns and feelings of weakness and hopelessness among citizens has led to the creation of a kind of emotional poverty among them. This leads to weakening of social norms. On the other hand, the results of this research show that the structure of families is undergoing change in the current time point. A major portion of this change should be searched in the tendency of Iranians and Iranian families towards modernity. Modernization has destructed various aspects of life in the context of communications and experiences and social pathologies in traditional families. In fact, by way of transfer of modern values and norms to families of the next generation, it has in a way been influential. Respondents in this research also believed that tendency of Iranian families to use satellite networks has led to change and transformation in traditional structures. Even without consideration of growth of industry, factors such as breadth of global markets, group media, city services, health care, education and transportation and etc have at times led to formation of families with modern structure where the function of these families has changed learning from other societies and by transfer from one culture to another. Undoubtedly, formation of such families has had positive and negative consequences. Results of research show that in causality of social problems of families of martyrs and veterans, the same factors are involved that are more 
or less found in other families. Yet, lack of father has had little effect on addiction, divorce or suicide of family members. Additionally, in analysis of results obtained, it can be assumed that even though governments in our country have taken effective actions for decreasing level of social problems in society in general and among families or martyrs, yet, need for increased actions and interventions persist.

\section{Suggestions}

Evaluate reasons for gravitation of veterans to substances of abuse and addiction in a scientific research.

Evaluate the relationship between demographic and economic traits of veterans and families of martyrs with social problems among them in a research study.

The foundation of martyrs and matters of veterans should by way of treatment centers take effective actions for treatment of addiction in veterans and children of martyrs afflicted with addiction.

By way of expansion of counseling and guidance offices at the level of offices of the martyrs' foundation, the possibility of access of families of martyrs to counseling should be increased so necessary prevention of divorce can be performed.

In counseling centers of the martyrs' foundation, while rapidly identifying individuals with suicidal ideation, there is need for provision of means for treatment and follow up of their physical and psychological condition.

By way of increased level of awareness of families of martyrs, veterans and their children, risky behavior should be explained to them so the possibility for prevention of social issues is reduced.

By way of expansion and development of non- profit organizations, social victims should be helped so the consequences and negative effects of social pathology on families of martyrs are minimized.

\section{References}

Ahmadi, Habib (2008). Theory of social deviation. Shiraz: Zar, $1^{\text {st }}$ edition.

Ahmadpanah, Emaddedin (no date). Evaluation of level of gravitation to addiction among children of martyrs. MS Dissertation, Psychology, University of Shahed, Guidance Professor: Mohammad Reza Naiinian.

Banijamal, Sh; Nafisi Izadi, SM (2004). Root analysis of causes of family disruption in relation with psycho-social traits of girls and boys before marriage. Journal of Developmental Sciences and Psychology of Shahid Chamran University, Ahvaz, 3.

Doroudi, A; Rezvani, M (no date). Pathology of families of the city of Mashad and comparison of methods of family education. First National Congress of Pathology of Marital Life in the City of Isfahan and Presentation of a Model for Pathology of Couples' Lives. MS Dissertation, University of Isfahan.

Enzioni, Amitai (2004). Organizational control, Peter: Modern Sociology (Translation: Hassan Pouyan). Tehran: Ghapkhash Publications, 1 st edition.

Haji Dehabadi, Mohammad Ali (1999-2000 second semester). Ethical relations and homicidal policy. MS Dissertation, Punitive Law and Criminology, Ghom, Monir University, 197 pages.

Jahanara, Mohammad Reza; Edalatkhah, Iman (2005). Evaluation of coping skills against stress among children of martyrs of the province of Kerman. Scientific and Research Journal of Teb, no 12, year 2, 14 pages.

Mohammadian, Rasoul (no date). Evaluation of the level of prevalence of psychological disorders among children of martyrs and nonmartyrs. MS Dissertation, Clinical Psychology, University of Well-Fare and Rehabilitation Sciences.

Rahmatollahi, Reza (no date). Evaluation of factors influential on occurrence of divorce in families attending forensic medicine in the city of Mashad. MS Dissertation, Developmental Sciences, University of Ferdowsi, Mashad.

Sadigh Sarvestani, Rahmatollah (no date). Social pathology. MS Class Notes, Tehran: College of Social Sciences, University of Tehran.

Sumner, Collin (2003) [2004] . the social nature of crime and deviance. In summer, (ad). The Black well companion to criminology. Mainstreet: Blackwell publication. Pp.3.31.

Lawson, T\&J. Garrod (2008). Dictionary of sociology. London: Fitzory Dear Born publishers.

www.irdc.ir/fa.conent.107+4734/defu.t.aspx.

www. Parsine.com/fa 